\title{
North Pole Car Wash: A Teaching Case Demonstrating The Advantages Of Accrual Basis Accounting
}

Paul M. Clikeman, University of Richmond, USA

\begin{abstract}
Given the significance of accrual accounting to financial reporting, it is important for students to understand why accounting standard setters have chosen accrual basis over cash basis accounting. This teaching case illustrates the superiority of accrual basis earnings over cash flows when financial statement users wish to evaluate past operating performance and/or predict future performance. The case, which requires only 20-25 minutes of class time, enables students to discern for themselves the relative advantages of accrual accounting.
\end{abstract}

Keywords: Cash Basis Accounting; Accrual Accounting; Earnings

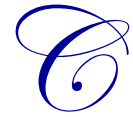

ash basis accounting is relatively easy for novice accounting students to understand. An enterprise sums the cash receipts collected from its customers and subtracts the cash payments for costs such as wages, utilities, and taxes. The resulting net increase or decrease in cash is one measure of the enterprise's operating success. Net operating cash flow conveys information about the cash available for investment in long-term assets or distribution to investors and creditors.

Despite the simplicity and intuitive appeal of cash accounting, both U.S. Generally Accepted Accounting Principles (GAAP) and International Financial Reporting Standards (IFRS) require companies to measure earnings and prepare their financial statements using the accrual basis of accounting. Accrual accounting is significantly more complicated than cash basis accounting because it requires estimates. For costs such as warranties and post-retirement health benefits, accrual accounting requires companies to report estimated expenses years, or even decades, before payments are made and the actual costs are known. Recording estimates increases the risk of error and bias in the financial statements.

Given the simplicity of cash basis accounting and the relative complexity of accrual accounting, novice accounting students have every right to ask why U.S. GAAP and IFRS require the accrual basis. What are the comparative benefits of accrual accounting, and are the benefits large enough to justify the accrual basis's added difficulty?

This article describes a short teaching case that demonstrates the superiority of accrual basis earnings over operating cash flows when financial statement users wish to evaluate past operating performance or predict future performance. The case, which requires only 20-25 minutes of class time, enables students to discern for themselves the relative advantages of accrual accounting. It is appropriate for use in undergraduate or MBA introductory financial accounting courses.

\section{ACCRUAL BASIS ACCOUNTING}

Unlike cash basis accounting, which recognizes revenues when cash is received and recognizes expenses when cash is paid, the accrual basis of accounting records revenues according to the revenue recognition principle and records expenses according to the matching principle.

The revenue recognition principle states that revenues should be recognized in the financial statements during the period in which (1) the earnings process is substantially complete, and (2) the amount to be received can be reasonably 
estimated. In most situations, this results in revenues being recognized during the period in which goods are delivered to the customer or services are performed for the customer. In a transaction such as a sale of merchandise on credit, the revenue recognition principle may result in revenue being reported in an accounting period prior to cash being collected from the customer. In transactions such as airline tickets and magazine subscriptions, wherein customers typically pay in advance of receiving goods or services, the revenue recognition principle may result in revenue being reported in an accounting period subsequent to cash being collected from the customer.

The matching principle states that expenses that are closely related to particular revenue transactions should be reported in the same accounting period when the revenue is recognized. For example, cost of goods sold and sales commissions should be recognized as expenses in the same accounting period in which the related sales revenue is reported. Expenses such as executive salaries and interest expense, which are not closely associated with identifiable revenues, should be recognized when incurred or in some systematic fashion. The matching principle requires some costs to be reported as expenses prior to cash being paid, as when a company consumes electricity during one accounting period but pays the utility bill during a subsequent period. Conversely, when an enterprise purchases inventory for cash in one accounting period and sells the goods in a subsequent accounting period, the expense will be reported in an accounting period after the cash was paid.

Accounting standard setters consider the needs of investors, creditors, auditors, regulators, and financial statement preparers. Both American and international accounting standard setters have concluded that accrual accounting is superior to cash basis accounting. Statement of Financial Accounting Concepts No. 1: Objectives of Financial Reporting by Business Enterprises (FASB 2008a, para. 44) states that accrual basis earnings provide "a better indication of enterprise performance than information about current cash receipts and payments." Statement of Financial Accounting Concepts No 6: Elements of Financial Statements (FASB 2008c, para. 144) asserts that shortterm cash receipts and outlays "cannot indicate whether or to what extent an enterprise is successful or unsuccessful." The International Accounting Standards Board's Framework for the Preparation and Presentation of Financial Statements (IASB 2012, para. 22) claims that accrual basis accounting is "most useful to users in making economic decisions."

There are several professed advantages of accrual accounting over cash basis accounting. First, by recognizing revenues when earned, accrual accounting provides a superior measure of the firm's accomplishments each period. Selling goods to a credit-worthy customer increases an entity's wealth; collecting the cash merely replaces one liquid asset with another. Second, by matching expenses with related revenues, accrual accounting provides a superior measure of the firm's profitability. A retailer may purchase inventory on credit in one period, pay the vendor in a second period, sell the goods on credit in a third period, and collect cash from the customer in a fourth period. Only by subtracting the cost of goods sold from the related sales revenue, within a single period, can an entity determine its profit on the sale. Finally, recognizing non-cash transactions in the financial statements provides useful information about future cash flows. Recognizing receivables for revenues earned, but not yet collected, provides information about future cash receipts. Recognizing liabilities for expenses incurred, but not yet paid, provides information about future cash payments.

\section{TEACHING CASE: NORTH POLE CAR WASH}

The following teaching case illustrates the superiority of accrual basis earnings over cash flows when financial statement users wish to evaluate past operating performance and/or predict future performance. SFAC No. 1 identifies evaluating operating performance and predicting future earnings as two of the most common uses of financial statements (FASB 2008a, para. 47).

The case involves a fictional automated car wash that earns revenue by washing cars for customers who either purchase coupons in advance or pay cash at the time of service. The only expenses addressed in the case are supplies and water. Although an actual car wash would have additional expenses (e.g., depreciation and taxes), the two expenses addressed in the case are sufficient to illustrate differences in the timing of expense recognition between cash basis and accrual accounting while keeping the mathematical computations to a minimum. To further simplify the case, we assume the car wash is open only three months per year. 


\section{Facts:}

North Pole Car Wash (NP), which is located in Fairbanks Alaska, is open only during June, July, and August each year - it is buried under snow and ice the other nine months. The following information is available for the most recent year.

a. NP sold 700 coupon books in June for $\$ 12$ per book. Each book contains six coupons. Each coupon can be redeemed for one car wash. In June, 1,400 coupons were redeemed; in July 1,500 were redeemed, and in August 1,300 were redeemed.

b. Customers who do not have coupons pay $\$ 3.00$ cash for each car wash. During June, 1,600 customers paid cash; during July, 1,800 customers paid cash; and during August, 1,500 customers paid cash.

c. NP purchased $\$ 3,000$ of detergent and car wax on account in June. NP paid for the supplies in July. In June, $\$ 1,000$ of supplies were used; in July, $\$ 1,100$ of supplies were used; and in August, \$900 of supplies were used.

d. During the first week of each month, NP receives a bill for the water used in the previous month. NP paid water bills of \$1,800 in July, \$2,000 in August, and \$1,600 in September.

\section{Requirements:}

1. Prepare a schedule showing NP's cash receipts, cash payments, revenues, and expenses for each month.

2. Prepare brief answers to each of the following questions:

a. Are the cash payments in a given month logically related to the month's cash receipts? Are the expenses in a given month logically related to the month's revenues?

b. You have been asked to evaluate the car wash's performance. Which month was the "best"? Did you answer based on cash flows or earnings? Why? Does the cash flow information allow us to evaluate the relative operating performance during each month? Does the income statement allow us to evaluate the relative operating performance during each month?

c. Assume today is June 30. Using only the cash flow statement for the month of June, could you make a reasonable prediction of what the cash flows would be for the remainder of the summer? Using only the income statement for the month of June, could you make a reasonable prediction of what the earnings would be for the remainder of the summer?

d. Which information, operating cash flows or accrual basis revenues and expenses, do you think is more useful to decision makers? Why?

\section{RECOMMENDED SOLUTION}

The first case requirement is to prepare a schedule showing the cash receipts, cash payments, revenues, and expenses for each month. Table 1 shows the completed schedule with explanations as to how various amounts were calculated. 
Table 1. Schedule of Cash Receipts, Cash Payments, Revenues and Expenses

\begin{tabular}{|c|c|c|c|c|c|c|c|c|}
\hline \multicolumn{5}{|c|}{ Cash Basis } & \multicolumn{4}{|c|}{ Accrual Basis } \\
\hline & June & July & Aug. & Sept. & & June & July & Aug. \\
\hline Cash Receipts: & & & & & Revenues: & & & \\
\hline Coupon books ${ }^{(1)}$ & $\$ 8,400$ & $\$ 0$ & $\$ 0$ & $\$ 0$ & Coupons $^{(3)}$ & $\$ 2,800$ & $\$ 3,000$ & $\$ 2,600$ \\
\hline Cash sales $^{(2)}$ & $\$ 4,800$ & $\$ 5,400$ & $\$ 4,500$ & $\$ 0$ & Cash sales $^{(2)}$ & $\$ 4,800$ & $\$ 5,400$ & $\$ 4,500$ \\
\hline & $\$ 13,200$ & $\$ 5,400$ & $\$ 4,500$ & $\$ 0$ & & $\$ 7,600$ & $\$ 8,400$ & $\$ 7,100$ \\
\hline Cash Payments: & & & & & Expenses: & & & \\
\hline Supplies & $\$ 0$ & $\$ 3,000$ & $\$ 0$ & $\$ 0$ & Supplies $^{(4)}$ & $\$ 1,000$ & $\$ 1,100$ & $\$ 900$ \\
\hline Water & $\$ 0$ & $\$ 1,800$ & $\$ 2,000$ & $\$ 1,600$ & Water ${ }^{(5)}$ & $\$ 1,800$ & $\$ 2,000$ & $\$ 1,600$ \\
\hline Net Cash Flow & $\$ 13,200$ & $\$ 600$ & $\$ 2,500$ & $(\$ 1,600)$ & Net Income & $\$ 4,800$ & $\$ 5,300$ & $\$ 4,600$ \\
\hline
\end{tabular}

(1) 700 coupon books @ $\$ 12=\$ 8,400$ collected in June.

(2) For customers who pay cash, revenue is recognized at the same time cash is received. June: 1,600 cars $@ \$ 3=\$ 4,800$. July: 1,800 cars @ $\$ 3$ $=\$ 5,400$. August: 1,500 cars $@ \$ 3=\$ 4,500$.

(3) A coupon book sells for $\$ 12$ and contains six coupons, resulting in a price of $\$ 2$ per coupon. Under accrual accounting, NP recognizes revenue when the coupons are redeemed for car washes. June: 1,400 cars @ $\$ 2=\$ 2,800$. July: 1,500 cars $@ \$ 2=\$ 3,000$. August: 1,300 cars @ $\$ 2=$ $\$ 2,600$.

(4) Under accrual accounting, the expense equals the cost of the detergent and wax used within the month.

(5) Under accrual accounting, the expense equals the cost of the water used within the month.

After the company's cash flows, revenues, and expenses are presented side-by-side, the following discussion questions enable students to discover for themselves the relative advantages of accrual accounting over the cash basis of accounting.

\section{a. Are the cash payments in a given month logically related to the month's cash receipts? Are the expenses in a given month logically related to the month's revenues?}

Students should easily conclude after examining the cash flows on the left side of Exhibit 1 that the cash payments in a given month are unrelated to the month's cash receipts. During June, the car wash had cash receipts but no cash payments, while during September, the car wash paid \$1,600 with no cash receipts. NP had both cash receipts and cash payments during the intervening two months, but it is difficult to find any causal or otherwise logical relationship between the amounts collected and the amounts paid within a given month. Net cash flow is a dubious measure of performance because it is merely the numerical difference between two unrelated numbers.

Conversely, students should determine, after reflection, that the expenses in each month are closely related to the month's revenues. During June, the car wash earned \$7,600 of revenue by washing 3,000 cars. ${ }^{1}$ The accrual basis expenses recognized during June (i.e., $\$ 1,000$ for supplies and $\$ 1,800$ for water), represent the costs incurred while washing those 3,000 cars. Similarly, the expenses recognized in July and August represent the costs incurred while servicing each of those month's customers. This illustrates the matching principle. The costs of the water and other supplies consumed while washing cars are recognized as expenses in the same accounting period with the revenues earned by washing the cars. Each month's net income, therefore, represents the excess of the revenues earned from washing cars over the costs of performing the work. This makes net income a meaningful measure of each month's operating success.

b. You have been asked to evaluate the car wash's performance. Which month was the "best"? Did you answer based on cash flows or earnings? Why? Does the cash flow information allow us to evaluate the relative operating performance during each month? Does the income statement allow us to evaluate the relative operating performance during each month?

This question asks students to evaluate historical performance. Statement of Financial Accounting Concept No. 2, Qualitative Characteristics of Accounting Information (FASB 2008b, I51) states that accounting information is relevant if it has "feedback value," that is, if it can be used to measure or evaluate past performance. External financial statement users, such as investment fund managers, frequently compare each quarter's numbers with those of the previous quarter to discern whether the company's performance is improving or deteriorating. Internal accounting

${ }^{1} 1,400$ coupons redeemed plus 1,600 cash customers equals 3,000 car washes. 
users, such as corporate executives, often review monthly financial reports to track the performance of the operations under their control.

Students quickly recognize that it is difficult to evaluate each month's operating performance using only the cash flows on the left side of Exhibit 1. June's large positive net cash flow did not occur because of any superior decisions or efforts made during the month; it is merely the result of selling coupons that will be redeemed in subsequent months. Reporting June's cash receipts alone, without revealing the costs incurred during the month or NP's obligation to provide future car washes, may lead a financial statement user to overestimate the entity's performance. September's negative net cash flow resulted from paying a residual water bill after operations had ceased for the year. Although the net cash flows of the two months differ dramatically, it makes little sense to say that the car wash performed better in June than in September.

Conversely, students should be confident concluding, based on the accrual accounting information on the right side of Exhibit 1, that the car wash performed better in July than in June, and better in June than in August. North Pole Car Wash must do two things to succeed: (1) wash cars, and (2) limit costs such that the revenues earned from washing cars exceed the costs of performing the work. Under accrual accounting, the revenues recognized each month provide a meaningful measure of the amounts earned by washing cars. Because of the application of the matching principle, the expenses recognized each month represent the costs associated with servicing each month's customers. Higher amounts of net income indicate that the enterprise serviced more customers and/or was more successful at controlling costs.

c. Assume today is June 30. Using only the cash flow statement for the month of June, could you make a reasonable prediction of what the cash flows would be for the remainder of the summer? Using only the income statement for the month of June, could you make a reasonable prediction of what the earnings would be for the remainder of the summer?

This question asks students to predict future operating performance. Statement of Financial Accounting Concepts No. 2, Qualitative Characteristics of Accounting Information (FASB 2008b, para. 51) states that accounting information is relevant, not only if it has "feedback value," but also if it as "predictive value." SFAC No. 2 goes on to explain that information need not itself be a prediction in order to have predictive value (FASB 2008b, para. 53). Financial statement readers often use information about an entity's past operations and current financial position to form expectations about future performance.

Students readily recognize that a financial statement user, given June's cash flow statement without knowledge of subsequent transactions, could not possibly forecast July through September's widely fluctuating cash flows. The coupon books sold during June provide an immediate cash inflow, but also obligate the car wash to spend cash washing cars in the future. Unfortunately, June's cash flow statement provides absolutely no information regarding how much the operating costs eventually will be.

June's accrual basis revenues and expenses, however, provide a clear indication that the car wash is likely to remain profitable and generate a positive long-term cash flow. We know from June's positive net income that NP is able to wash cars at a cost less than the price it charges customers. NP washed 3,000 cars in June, and revenues exceeded associated costs by $\$ 4,800$. If NP can attract more than 3,000 customers in future months, its profits will likely increase (e.g., July). If NP services fewer customers, its profits can be expected to decrease, but are likely to remain positive (e.g., August). Using June's income statement and assuming no extraordinary changes in volume, a financial statement user could probably predict with reasonable confidence that, in each subsequent month, NP will neither earn tens of thousands of dollars of profit nor suffer a loss.

\section{d. Which information, operating cash flows or accrual basis revenues and expenses, do you think is more useful to decision makers? Why?}

After discussing the preceding three questions in class, students should need little additional prompting to conclude that accrual accounting provides more useful information than cash basis accounting. Thus, students are able to discern 
for themselves why accounting standard setters require companies to prepare their financial statements using the accrual basis of accounting.

\section{CLASSROOM IMPLEMENTATION}

I have used this teaching case in both undergraduate and MBA introductory financial accounting courses for more than 20 years. I use the case during the third week of the semester, shortly after introducing the revenue recognition and matching principles. After learning that revenues and expenses may be reported in the income statement long before or after the related cash flows, students are usually receptive to hearing why accountants have chosen to use accrual accounting rather than cash basis accounting.

I distribute to the students a one-page handout containing the case facts, a blank schedule of cash flows, revenues, and expenses, and the four discussion questions. I give the students approximately ten minutes to complete the schedule of cash flows, revenues, and expenses, working independently or with neighbors. An advantage of the case is that it demonstrates timing differences between cash flows, revenues, and expenses while keeping the mathematical calculations simple enough that most students can complete the schedule within ten minutes. ${ }^{2}$

After projecting the completed Exhibit 1 on a screen and answering any questions about how the numbers were calculated, I spend the next 10-12 minutes leading a discussion of the first three discussion questions. I resist giving answers to the questions, but continue asking successive students to address each question until a consensus forms that:

- The matching principle results in a logical relationship between each month's revenues and expenses while there is not necessarily any logical relationship between a given month's cash receipts and cash payments.

- We can evaluate the relative operating performance of any two months by comparing their accrual basis net incomes, but net cash flow provides a poor measure of short-term operating performance.

- Knowing June's revenues and expenses enables a financial statement user to forecast the future success of the car wash, but June's cash flows reveal little about the long-term viability of the business.

Only very rarely do enough students have trouble reaching the above conclusions that I have to ask follow-up questions to guide students toward the advantages of accrual accounting. After thoroughly discussing the first three questions, I ask students to vote via a show of hands whether they think cash or accrual basis accounting provides more useful information to decision makers. The majority in favor of accrual accounting has never been less than overwhelming.

After conducting the vote in which students decide for themselves that accrual accounting has advantages over cashbasis accounting, I remind students that financial statements users do not have to choose between receiving earnings information or cash flow information. Financial statements prepared according to U.S. GAAP and IFRS contain income statements that measure earnings using accrual accounting, but also contain cash flow statements that report the entity's cash receipts and payments. Sophisticated financial statement users read both statements and are adept at comparing net income with operating cash flows to anticipate future liquidity problems and evaluate earnings quality.

Occasionally, a perceptive student will point out that the cumulative cash receipts $(\$ 13,200+\$ 5,400+\$ 4,500=$ $\$ 23,100)$ equal the cumulative revenues $(\$ 7,600+\$ 8,400+\$ 7,100=\$ 23,100)$, and the cumulative cash payments $(\$ 3,000+\$ 1,800+\$ 2,000+\$ 1,600=\$ 8,400)$ equal the cumulative expenses $(\$ 1,000+\$ 1,800+\$ 1,100+\$ 2,000+$ $\$ 900+\$ 1,600=\$ 8,400)$. SFAC No. 1 acknowledges that reported earnings will equal net operating and investing cash flows over the life of an enterprise (FASB 2008a, para. 46). Over a sufficiently long time period, it makes little difference whether an entity uses cash or accrual basis accounting. But because users desire accounting information for time periods as short as years, quarters, and even months, it is important to use accrual accounting. The shorter the reporting period, the greater the probability that cash receipts will occur in a period different than the related costs and the efforts made to earn the revenues.

\footnotetext{
${ }^{2}$ To conserve class time, an instructor may wish to distribute the assignment at the end of one class meeting with instructions to complete the schedule and consider the discussion questions prior to a subsequent class meeting.
} 
Instructors who are interested in using the North Pole Car Wash teaching case are invited to visit http://goo.gl/AgDwy8. This web site contains a Word file containing the case that instructors can print for distribution to their students. Alternatively, for instructors who would rather have their students complete Exhibit 1 in Excel, there is an Excel file containing the case and discussion questions. There is also a deck of PowerPoint slides, which instructors can use during class. Finally, instructors who do not want to devote class time to the case may have their students watch a video explanation of the case at https://youtu.be/L6TaFZSp5tM.

\section{CONCLUSION}

Given the significance of accrual accounting to financial reporting, it is important for students to understand why accounting standard setters have chosen accrual basis over cash basis accounting. The difficulties of accrual accounting become apparent within the first few weeks of an introductory financial accounting course. Accountants must record estimated revenues and expenses today for cash flows that may not happen for years in the future. The advantages of accrual accounting are less obvious and may not be explained well in introductory financial accounting textbooks. The teaching case described in this article requires only 20-25 minutes of class time and enables students to discern for themselves the relative advantages of accrual accounting.

\section{AUTHOR BIOGRAPHY}

Paul M. Clikeman, Ph.D., teaches auditing and financial accounting at the University of Richmond. He serves on the editorial boards of Advances in Accounting Education and Issues in Accounting Education, and is the author of many professional journal articles on auditing and fraud examination. E-mail: pclikema@richmond.edu

\section{REFERENCES}

Financial Accounting Standards Board (FASB). (2008a). Statement of Financial Accounting Concepts No. 1: Objectives of Financial Reporting by Business Enterprises. Norwalk, CT: Financial Accounting Foundation.

Financial Accounting Standards Board (FASB). (2008b). Statement of Financial Accounting Concepts No. 2: Qualitative Characteristics of Accounting Information. Norwalk, CT: Financial Accounting Foundation.

Financial Accounting Standards Board (FASB). (2008c). Statement of Financial Accounting Concepts No. 6: Elements of Financial Statements. Norwalk, CT: Financial Accounting Foundation.

International Accounting Standards Board (IASB). (2012). Framework for the Preparation and Presentation of Financial Statements. London: IFRS Foundation. 


\section{NOTES}

